\title{
ISOLATION AND CHARACTERIZATION OF THE FOLATE-BINDING PROTEIN FROM COW'S MILK
}

\author{
by \\ IB SVENDSEN, BRIAN MARTIN and TORBEN GRAVES PEDERSEN \\ Department of Chemistry, Carlsberg Laboratory, \\ Gamle Carlsberg Vej 10, DK-2500 Copenhagen Valby \\ and \\ STEEN INGEMANN HANSEN, JAN HOLM and JØRGEN LYNGBYE \\ Department of Clinical Chemistry, Research Division, \\ Central Hospital, Helsevej 2, DK-3400 Hillerød
}

Keywords: Folate-binding protein, milk, purification, amino acid composition, molecular weight, partial sequence

\begin{abstract}
The folate-binding protein from cow's milk has been purified in milligramme scale by combination of ionexchange chromatography and affinity chromatography. The molecular weight has been determined by sedimentation equilibrium ultracentrifugation and found to be $30,000 \pm 2,000$. The amino acid composition is compatible with this value. The molecule contains six disulphide bridges and no free SH-groups. The three per cent carbohydrate content was accounted for by six glucosamine residues per mole of protein. About 50 per cent of the amino acid sequence has been delineated, including the $\mathrm{N}$-terminal sequence and the $\mathrm{C}$-terminal sequence. Isoelectric focusing gave rise to four major peaks with isoelectric points ranging from 8.5 to 7.6 , but no heterogeneity was observed in the sequence.
\end{abstract}

Abbreviations: EDC $=$ N-ethyl-N'-(3-dimethylaminopropyl)carbodiimide hydrochloride, THEED = $\mathrm{N}: \mathrm{N}: \mathrm{N}^{\prime}: \mathrm{N}$-tetrakis (2-hydroxyethyl) ethylenediamine, Tris = Tris (hydroxymethyl) aminomethane, MES = 2-(N-morpholine) ethanesulfonic acid, FBP = folate-binding protein, FBC = folate-binding capacity, polybrene $=$ 1,5-dimethyl-1,5-diazaundecamethylene polymethobromide. 


\section{INTRODUCTION}

Proteins which specifically bind folate have previously been isolated from various body fluids and tissues $(33,20)$ including cow's milk $(14,30)$. The function of these proteins is not yet fully understood, but they may play a role in the utilization of folic acid and in the storage and transport of this vitamin (33). Binding studies have shown that a protein from cow's milk binds folate in a cooperative manner over a wide range of $\mathrm{pH}(13,14,19)$. However, in order to understand fully the mechanism by which folate binding takes place it is necessary to obtain as many physico-chemical parameters related to the protein as possible. Apart from the folate binding proteins from goat's milk (29) and the membrane of Lactobacillus casei (16) for which partial characterizations have been published, proteins from other sources have been isolated in amounts too small to allow such a characterization.

In the present paper a method is described for the purification of a folate binding protein from cow's milk in milligramme quantities, and this protein is characterized by determination of the molecular weight, amino acid composition, partial amino acid sequence and isoelectric point(s).

\section{MATERIALS AND METHODS}

\subsection{Materials}

Whey powder was kindly supplied by Statens Forsøgsmejeri, Hillerød, Denmark. Methotrexate, Lederle was from American Cyanamid Company, N.Y.. N-ethyl-N'-(3-dimethylaminopropyl)carbodiimide hydrochloride (EDC), from Merck, Darmstadt, Germany. [ ${ }^{3} \mathrm{H}$ ] folate was from Radiochemical Centre, Amersham, England. Bio-Gel P-30 and P-6 were from Biorad Laboratories, Richmond, Calif., while CM-Sepharose CL-6B and AH-Sepharose were products from Pharmacia, Uppsala, Sweden. For sequence determinations the following chemicals were used: N:N:N':N'-tetrakis (2-hydroxyethyl) ethylenediamine (THEED) was obtained from ICN-K \& K Laboratories, Plainview, New York, and used without further purification. Ethyl acetate (UV solvent grade) was purchased from Merck. Both THEED and ethyl acetate were found to be free of aldehydes as determined by the Tollens' reaction (5). Heptane was from Fluka, Switzerland, and phenylisothiocyanate, heptafluorobutyric acid, 1-propanol, trifluoroacetic acid, benzene, polybrene and butylchloride were all sequenal grade products of Pierce Eurochemie B.V., Rotterdam, Holland. The 0.1 $\mathrm{M}$-THEED used as the coupling buffer in place of $1 \mathrm{M}$-Quadrol and the ethyl acetate containing $15 \%$ 1-propanol were prepared according to the procedure of BEGG and MoRGAN (1).

\subsection{Preparation of folate binding protein (FBP)}

Whey powder was prepared from cow's whey by vacuum evaporation at $68^{\circ} \mathrm{C}$ followed by spray-drying at $180^{\circ} \mathrm{C}$. The content of FBP in whey powder varied from preparation to preparation. Only preparations with a reasonably high content of FBP (see below) were used in the isolation prodecure.

Whey powder was suspended in water (1.3 liters of water per $1 \mathrm{~kg}$ of whey powder). The slurry was stirred for one hour and filtered through a coarse filter paper at $20^{\circ} \mathrm{C}$ in $15-20$ $\mathrm{hrs}$. The filtrate was dialyzed, first against water for $48 \mathrm{hrs}$ at $4^{\circ} \mathrm{C}$, then against $0.03 \mathrm{M}$-MES buffer $\mathrm{pH} 6.3(0.03 \mathrm{M}$ in Na-ions) for $24 \mathrm{hrs}$. After dialysis the concentrations of Na- and Kions were measured by flame-photometry on an Instrumentation Laboraty flame-photometer, Model 543. The concentrations of $\mathrm{Na}$ - and $\mathrm{K}$ ions were found to be $40-50 \mathrm{~mm}$ and $5-15 \mathrm{~mm}$, respectively. The ability to bind folate was controlled by dialysis experiments in a Trisbuffer, pH 7.4 as previously described $(13,14)$. Only whey powder extracts having a folate binding capacity of above 0.1 moles per liter were used for further purification.

One to two liters of extract (equivalent to a binding capacity of $0.2-0.4$ umoles of folate) were applied to a CM-Sepharose CL-6B column $(2.5 \times 51 \mathrm{~cm})$ which had been equilibrated with $0.03 \mathrm{M}$-MES buffer, $\mathrm{pH} 6.3$ at $5^{\circ} \mathrm{C}$. (Na-ion concentration was $0.03 \mathrm{M}$ ). The column was rinsed with 1.5 liters of the same buffer at a flow-rate of $240 \mathrm{ml} \cdot \mathrm{hr}^{-1}$. FBP was then eluted with a $0.17 \mathrm{M}$-Tris buffer at $\mathrm{pH} 7.4,1 \mathrm{M}$ in $\mathrm{NaCl}$. The fractions containing FBP were collected (total volume approx. $150 \mathrm{ml}$ ). The pooled 
fractions from ten chromatographic runs were concentrated ten fold on an Amicon TCF 10 concentrator using a PM 10 membrane filter.

An affinity matrix was prepared as described by KaUfMANN (21) by reaction of metrotrexate with carbodiimide (EDC) activated AH-Sepharose. A column, $0.8 \times 5 \mathrm{~cm}$, was equilibrated

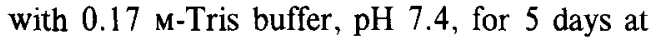
$5^{\circ} \mathrm{C}$ and a flow rate of $30 \mathrm{ml} \cdot$ hour $^{-1} .200 \mathrm{ml}$ of the concentrate was applied with the same flowrate followed by $50 \mathrm{ml}$ of Tris buffer. Protein contaminants which were bound to the column in an unspecific manner were eluted with Tris buffer which was made $1 \mathrm{M}$ in $\mathrm{NaCl}$. (Flow-rate $5 \mathrm{ml}$ hour ${ }^{-1}$ ) followed by $50 \mathrm{ml}$ of Tris buffer without $\mathrm{NaCl}$. The FBP was eluted with $0.2 \mathrm{M}$ Na-acetate buffer at pH 3.5 (Flow-rate 5 ml'hour $\left.{ }^{-1}\right)(31)$.

\subsection{Binding assays}

The binding capacity of FBP was checked by dialysis against Tris buffer $\mathrm{pH} 7.4$, containing [3 $\mathrm{H}]$ folate, for 24 hours and cooperativity was demonstrated in agreement with previous findings $(13,14)$.

\subsection{SDS-gelelectrophoresis}

SDS-polyacrylamide gelelectrophoresis was conducted in a $0.05 \mathrm{M}$-imidazole buffer of $\mathrm{pH} 7.0$ using an LKB 2117 multiphor equipment (7).

\subsection{Amino acid analysis}

Duplicate samples were hydrolyzed in constant boiling $\mathrm{HCl}$ for 24, 48 and 72 hours in evacuated, sealed tubes at $110^{\circ} \mathrm{C}$. The analysis were performed on a Durrum model D-500 amino acid analyzer. Serine and threonine were determined by extrapolation to zero-time hydrolysis, while the values from 72 hours of hydrolysis were used for valine and isoleucine. Tryptophan was determined by hydrolysis in methanesulphonic acid (26) and by spectrophotometry according to GoODWIN and MORTON (10). The content of total cysteine was determined by conversion of cysteines and cystines to cysteic acid by performic acid oxidation (17). Free cysteines were determined spectrophotometrically with ELLMAN's reagent in $8 \mathrm{M}$ urea (6).

\subsection{Carbohydrate determinations}

were performed with the phenolsulphuric acid method described by DuBors et al. (4). Glucose was used as standard. Glucosamine was determined by hydrolysis of FBP in evacuated, sealed tubes in constant boiling $\mathrm{HCl}$ for 1,3 , and 6 hours at $100^{\circ} \mathrm{C}$. The values were extrapolated to zero-time hydrolysis.

\subsection{Isoelectric focusing}

was done in a $\mathrm{LKB}$ isoelectric focusing instrument, Model 8100. Ampholines covering the $\mathrm{pH}$-range $3-10$ were used in a $0.2 \%$ concentration at $4^{\circ}$. Equilibrium was established within 24 hours. At the end of the experiment fractions of $2 \mathrm{ml}$ were collected. The individual peaks were located from their absorbance at $\mathbf{2 8 0}$ $\mathrm{nm}$ and the isoelectric points determined by measuring the $\mathrm{pH}$ of the individual fractions.

\subsection{Determination of the molecular weight}

Ultracentrifugation was performed in a Spinco Model E ultracentrifuge using schlieren optics in the sedimentation velocity experiments and Raleigh interference optics in the sedimentation equilibrium experiments. The Yphantis meniscus depletion method as modified by Chervenko (2) was used in the molecular weight determination experiments. The partial specific volume, $\bar{v}$, was essentially calculated from the $\overline{\mathrm{v}}$ 's published for the individual amino acid residues (3), and hexoses (9).

\subsection{Determination of amino acid sequences}

was made by automated Edman degradation on a Beckman sequencer, Model $890 \mathrm{C}$ using the Beckman programme 122974. Instead of $1.0 \mathrm{M}$ Quadrol, THEED (1) was used in a $0.1 \mathrm{M}$ concentration (27). When peptides were sequenced, polybrene was added to the cup as described (28). Identification of PTH-amino acids was done by high pressure liquid chromatography using a Hewlett-Packard HPLC chromatograph, model 1084B. A Merck reverse phase column (RP-8; $10 \mu$ ) was used with a gradient elution system which was a slight modification of the one described by ZimMERMan et al. (34). Additional information was obtained by back- 
hydrolysis to the free amino acids (25) or by thin-layer chromatography on polyamide sheets (23).

\subsection{Determination of the C-terminal amino acid residues}

Approx. 25 nmoles FBP was dissolved in 150 $\mu \mathrm{l}$ of a $2.5 \mathrm{~mm}$-ethylmorpholinoacetate buffer, $\mathrm{pH} 7.0$ and $30 \mu \mathrm{l}$ removed for zero-time determination of free amino acids. Five $\mu 1$ carboxypeptidase $Y(24)$ were added from a stock solution of $1 \mathrm{mg} \cdot \mathrm{ml}^{-1}, 30 \mu \mathrm{l}$ aliquots were removed at suitable time intervals, and added to $5 \mu \mathrm{l} 1 \mathrm{M}$ $\mathrm{HCl}$ whereby the reaction was terminated. After drying, the aliquots, including the zero-time sample, were redissolved in a $\mathrm{pH} 2.2$ buffer and applied to the amino acid analyzer.

\subsection{Reduction and alkylation of FBP}

100 nmoles of FBP was dissolved in $2 \mathrm{ml}$ $0.13 \mathrm{M}$-Tris buffer, $\mathrm{pH} 7.5$ and $10 \mu \mathrm{l}$ EDTA was added. Nitrogen was bubbled through the solution for $20 \mathrm{~min}, 15 \mu \mathrm{l}$ mercaptoethanol was added and the reaction mixture left with stirring at room temperature for 16 hours. Twenty $\mu \mathrm{l}$ 4-vinylpyridine (8) was added, the solution purged with nitrogen for $2 \mathrm{~min}$ and then left at room temperature for two hours. The $\mathrm{pH}$ was lowered with acetic acid to 3.8 and the reaction mixture applied to a Bio-Gel P-6 column equilibrated with $30 \%$ acetic acid. The emerging protein peak was located by its absorbance at $280 \mathrm{~nm}$ and the relevant fractions pooled and lyophilized.

\subsection{Cyanogen bromide cleavage}

The reduced, alkylated FBP was redissolved in $1.2 \mathrm{ml} 70 \%$ formic acid and $57 \mathrm{mg} \mathrm{CNBr}$ added. The reaction mixture was left overnight at room temperature with stirring. It was then applied to a Bio-Gel P-30 column $(0.9 \times 100 \mathrm{~cm})$ and eluted with $30 \%$ acetic acid. Fractions of 1.5 $\mathrm{ml}$ were collected. Peaks were located by measuring the absorption at $280 \mathrm{~nm}$ and the relevant fractions pooled and lyophilized.

\section{RESULTS}

\subsection{Purification of folate binding protein}

It is obviously an advantage in the purification of FBP from milk to use whey powder prepared in pilot plant scale quantities as the starting material for the chromatographic procedures. However, the elevated temperatures used in the drying steps might possibly lead to denaturation of FBP. This was found not to be the case since it was demonstrated by binding assays that the FBP contained in whey powder was able to bind folate in a cooperative manner.

Chromatography on CM-Sepharose CL-6B leads to a 9-25 fold increase in the specific activity of FBP (Table I). SDS-gel electrophoresis of the eluted FBP containing fractions showed that at least six proteins were present (Figure 1A). In parallel experiments is has been demon-

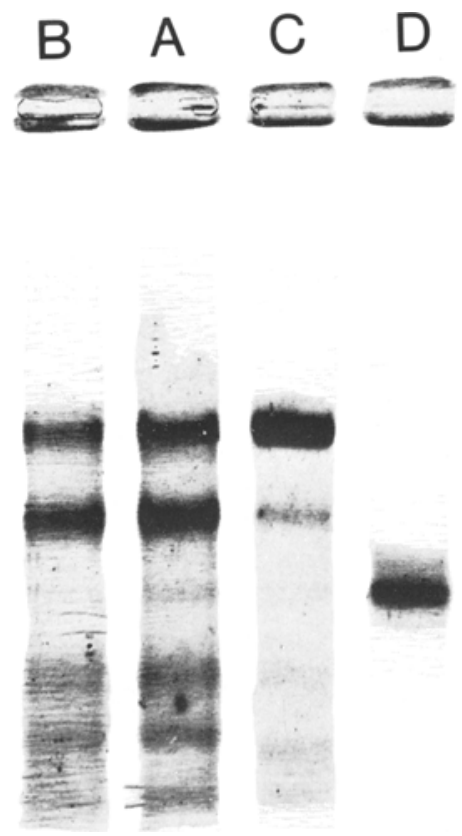

Figure 1. SDS-gelelectrophoresis at different stages of affinity chromatography. A: before application of the concentrated eluate from ion-exchange chromatography, (dilution 1:8). B: Material not retained by the affinity column, (dilution 1:8). C: First fraction of wimpurities" from elution with $0.17 \mathrm{M}$-Tris buffer, pH 7.4 containing $1 \mathrm{M}-\mathrm{NaCl}$ (undiluted). D: Fraction containing folate binding protein eluted with $0.2 \mathrm{M}$ acetate buffer, pH 3.5 (dilution 1:20). 
Table I

Purification of folate binding protein from whey-powder

\begin{tabular}{|c|c|c|c|c|c|c|}
\hline & Volume & $\begin{array}{l}\text { Folate } \\
\text { binding } \\
\text { capacity } \\
\text { (FBC) }\end{array}$ & $\begin{array}{l}\text { Protein } \\
\left(\mathrm{A}_{280 \mathrm{x}}\right. \\
\text { volume (1)) }\end{array}$ & nmol & Recovery & Purification \\
\hline & $\mathrm{ml}$ & $\mathrm{nmol}$ & arb. units & arb. units & $\%$ & 1 \\
\hline $\begin{array}{l}\text { Whey powder extract } \\
\text { applied to } \\
\text { CM-Sepharose CL-6B }\end{array}$ & 1000 & 420 & $16.91)$ & 25 & 100 & 1 \\
\hline $\begin{array}{l}\text { Eluted with Tris } \\
\mathrm{pH} 7.4,1 \mathrm{M}-\mathrm{NaCl}\end{array}$ & 150 & 320 & 1.35 & 23721 & 76 & 9 \\
\hline $\begin{array}{l}\text { Concentrate applied } \\
\text { to affinity column }\end{array}$ & 200 & 4700 & 7.40 & $6352)$ & $753)$ & 25 \\
\hline $\begin{array}{l}\text { Eluted with Tris } \\
\text { pH } 7.4,1 \mathrm{M}-\mathrm{NaCl}\end{array}$ & 30 & 36 & 0.07 & 514 & 0.8 & - \\
\hline $\begin{array}{l}\text { Eluted with } \\
0.2 \mathrm{M} \text {-acetate, } \mathrm{pH} 3.5\end{array}$ & 11 & 2600 & 0.33 & 78804) & 41 & 315 \\
\hline
\end{tabular}

1) Determined after removal of casein residual by filtering through a $0.2 \mu \mathrm{m}$ Gelman filter.

2) The specific activity varied much even within the same batch of whey powder and/or eluate from ionexchange chromatography $(0.2-0.7 \mu$ moles per arb. unit of protein. The reason is, that varying amounts of lactoperoxidase can be extracted from different batches of whey powder. This protein has a pl of about 9 and will consequently elute together with the folate binding protein on ion exchange chromatography.

3) This yield is an example. The yield varies normally from 60 to $90 \%$. An average of $75 \%$ has been used in the calculation of the yield from affinity chromatography.

4) From amino acid analysis and absorption measurement $A_{280 \mathrm{~nm}}^{1 \mathrm{~cm} .0 .1 \%}=2.35$ was calculated on the basis of a molecular weight of 29,000 . This leads to a specific activity of $18.3 \mu$ moles folate per $g$ protein.

strated that the band corresponding to the highest molecular weight is lactoperoxidase and the weak low-molecular weight bands represent $\beta$-lactoglobulin and $\alpha$-lactalbumin, respectively.

When the concentrated eluate from the ionexchange chromatography was applied to the affinity column $90-99 \%$ of the folate binding capacity was bound to the column (Table I). It is seen from Figure 1B that band No. 3 (counted from the point of application) has disappeared in the SDS-gel electrophoresis. The elution with Tris buffer containing $1 \mathrm{~m}-\mathrm{NaCl}$ is important, since impurities, amounting to about $20 \%$ of protein eluting from the affinity columm are eluted in this step. (Table I). Figure IC shows that it is primarily lactoperoxidase which is bound unspecifically.

The yield of FBP eluted from the affinity column was $55 \%$ of the amount applied, which is reasonable in comparison with SALTER et al. (30) who found $62 \%$ (Cow's whey). They eluted by means of an acetate buffer, $\mathrm{pH} 5.0$, which was $8 \mathrm{M}$ in carbamide. WAXMAN and SCHREIBER (32) who used a column with folate coupled to Sepharose and an equivalent elution technique as ours, got a yield of $39 \%$ (human milk). RuBINOFF et al. (29) got with the same technique a yield of $25 \%$ (goat's milk).

The specific activity of the resulting pure FBP was $18.3 \mu$ moles of folate per $g$ of protein. 
Similar results have been found by others. Thus, WaXMAN and Schreiber (32) found a FBC of $16.0 \mu$ moles per $\mathrm{g}$ of protein and RuBiNOFF et al. (29) found a FBC of $21.0 \mu$ moles per $g$ of protein in their purest products.

\subsection{Molecular weight determination by ultra- centrifugation}

Initial experiments using the sedimentation velocity technique showed that at $\mathrm{pH} 5.0$ the protein existed as a globular protein in the monomeric state, with a $\mathrm{s}_{20, \mathrm{w}}^{\circ}$ of $2.7 \mathrm{~S}$. Therefore, the molecular weight was determined at this $\mathrm{pH}$ by means of the sedimentation equilibrium technique. In Figure 2 is shown a plot of $\ln \mathrm{f}$ versus $\mathrm{x}^{2}$, where $f$ is the number of fringes which is proportional to the concentration. The straight line obtained shows that only a single molecular species is present. The molecular weight calculated from these data is 29,800 . The partial specific volume, $\overline{\mathrm{v}}$, was calculated as $0.711 \mathrm{ml} \cdot \mathrm{g}^{-1}$ on the basis of the relative amino acid composition and a carbohydrate content of $3.0 \%$. Calculations show that a variation of the carbohydrate content between five and fifteen per cent will only change the molecular weight by \pm 400 . Since $\bar{v}$ of carbohydrates is lower than $\bar{v}$ of amino acids, an increase in the carbohydrate content in a

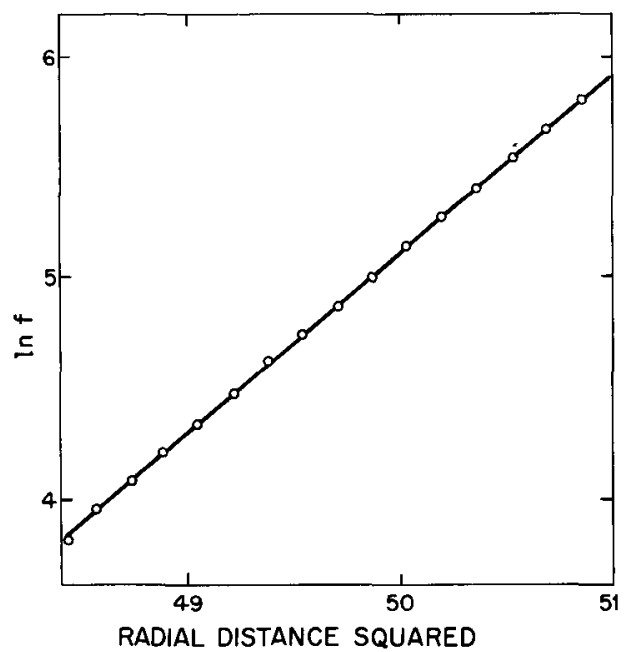

Figure 2. Plot of $f$ versus $\ln x^{2}$. Sedimentation equilibrium ultracentrifugation at $20^{\circ} \mathrm{C}$ of folate binding protein from cow's milk. pH was 5.0 . glycoprotein will lower its $\overline{\mathrm{v}}$. Used in the Svedberg equation, the smaller $\overline{\mathrm{v}}$ will lead to a smaller molecular weight. Thus, small uncertainties in the carbohydrate determination will effect the calculation of the molecular weight only slightly.

\subsection{Amino acid composition}

The amino acid composition of FBP based on a molecular weight of 29.000 and a carbohydrate content of $3 \%$ is shown in Table II. For comparison the amino acid composition of FBP from goat's milk is included (29). A close similarity is noted for most of the amino acids, the exceptions being Gly, Ala and Cys. No attempts have been made to determine the amide content of the protein. However, the basic isoelectric point(s) (see section 3.6) indicate that Glu and Asp exist to a larger extent in the amidated forms.

\section{Table II}

The amino acid composition of the folate binding protein from cow's milk

\begin{tabular}{lrr}
\hline Amino acid & Cow & Goat4) \\
\hline Aspartic acid & $24.00(24)$ & $(26)$ \\
Threonine 1$)$ & $14.04(14)$ & $(12)$ \\
Serine 1$)$ & $22.61(23)$ & $(21)$ \\
Glutamic acid & $25.97(26)$ & $(24)$ \\
Proline & $18.90(19)$ & $(22)$ \\
Glycine & $14.00(14)$ & $(29)$ \\
Alanine & $14.20(14)$ & $(22)$ \\
1/2 cystine2) & $11.65(12)$ & $(4)$ \\
Valine & $11.63(12)$ & $(16)$ \\
Methionine & $2.71(3)$ & $(3)$ \\
Isoleucine & $7.21(7)$ & $(10)$ \\
Leucine & $12.17(12)$ & $(15)$ \\
Tyrosine 1$)$ & $11.35(11)$ & $(7)$ \\
Phenylalanine 1$)$ & $11.95(12)$ & $(7)$ \\
Histidine & $8.25(8)$ & $(9)$ \\
Lysine & $12.29(12)$ & $(17)$ \\
Arginine & $13.72(14)$ & $(12)$ \\
Tryptophan 3$)$ & $(8)$ & n.d. \\
\hline
\end{tabular}

The numbers are averages of duplicate samples hydrolyzed for 24,48 and 72 hours. Integral numbers in parenthesis are nearest integer.

1) Extrapolated values. 2) Determined as cysteic acid after performic acid oxidation (17). 3) From acid hydrolysis in methanesulphonic acid (26) and spectrophotometry (10). 4) From reference (29). 
The monomeric molecule consists of approx. 240 residues. Titration of the protein with ELLMAN's reagent (6) under denaturing conditions showed the absence of free sulphydryl groups implying that the twelwe half cysteine residues form six disulphide bridges. Eight residues of Trp were found per mole of FBP from both acid hydrolysis in methanesulphonic acid (26) and spectrophotometry (10).

\subsection{Sequence determinations}

\subsection{1. $\mathrm{N}$-terminal sequence}

The determination of the $\mathrm{N}$-terminal sequence by automated Edman degradation showed the first 25 residues to be: Ala-Gln-Ala-Pro-ArgThr-Pro-Arg-Ala-Arg-Thr-Asp-Leu-Leu-AsnVal-Cys-Met-Asp-Ala-Lys-His-His-Lys-Ala-. Another peptide was present as a contaminant which amounted to about $10 \%$ of the total peptide material. The first fourteen residues were identified as: Ala-Arg-Thr-Asp-Leu-Leu-AsnVal-Cys-Met-Asp-Ala-Lys-His-, which are identical with residues 9 to 22 in the main sequence. Thus, this contaminant appears to have arisen from a limited proteolytic split of the intact protein indicating that only one peptide chain is present in the FBP molecule.

\subsubsection{C-terminal sequence}

Treatment of the protein with carboxypeptidase $\mathrm{Y}$ released two amino acids only. Isoleucine was found to be the C-terminal residue, followed by glycine, which was only released in small quantities. It is well-known that carboxypeptidase $\mathrm{Y}$ normally cleaves $\mathrm{C}$-terminal glycine residues very slowly (15). That only one Cterminal residue was found supports the suggestion that the molecule consists of only one peptide chain.

\subsubsection{Cyanogen bromide peptides}

According to the amino acid composition FBP contains three methionine residues per molecule which by cleavage with $\mathrm{CNBr}$ will lead to the production of four peptides. As seen in Figure 3, gel chromatography of a reaction mixture of previously reduced and alkylated FBP (100 nmoles) on Bio-Gel P-30 gave rise to three peaks

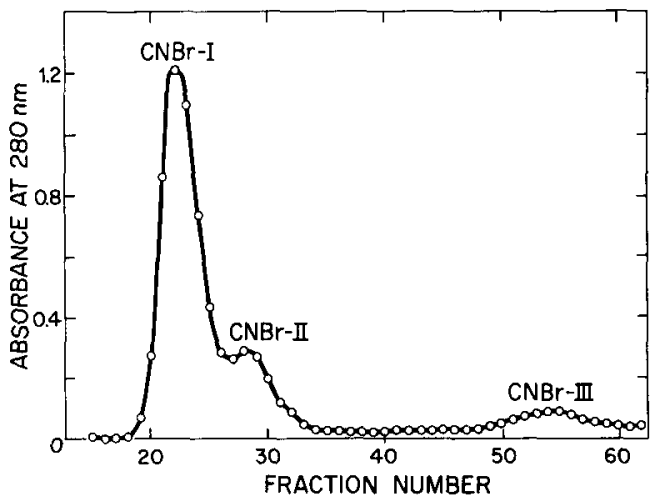

Figure 3. Gelfiltration on Bio-Gel P-30 $(0.9 \times 100$ $\mathrm{cm})$ of cyanogenbromide treated folate binding protein from cow's milk, which initially was reduced and alkylated. Eluted with $30 \%$ acetic acid. Flowrate six $\mathrm{ml}^{\text {hour-1. }}{ }^{-1}$. Fractions of $1.5 \mathrm{ml}$.

as judged by the absorbance at $280 \mathrm{~nm}$. These are named $\mathrm{CNBr}-\mathrm{I}, \mathrm{CNBr}-\mathrm{II}$ and $\mathrm{CNBr}$-III according to the order of elution from the column. The peptide content of these peaks was found from amino acid analyses to be between 60 and 80 nmoles. The peptides CNBr-I and $\mathrm{CNBr}$-II were rechromatographed and all three peptides were found to be pure by running a few steps in the sequencer. The $\mathrm{N}$-terminal peptide (CNBr-IV), which is 18 amino acids in length and lacks both tyrosyl and tryptophanyl residues, could not be located by measurement of absorbance at $280 \mathrm{~nm}$. The isolation of this peptide has not yet been attempted.

Amino acid analysis of CNBr-I showed that this was a peptide consisting of approx. 125 residues. It was sequenced through 30 residues as follows:

Glu-Pro-Ala-Cys-Lys-Arg-His-Phe-Ile-GlnAsp-Thr-Cys-Leu-Tyr-Glu-Cys-Ser-Pro-AsnLeu-Gly-Pro-Trp-Ile-Arg-Glu-Val-Asn-Gln-

Amino acid analysis of $\mathrm{CNBr}-\mathrm{II}$ showed this peptide to consist of 70 residues, the partial sequence of which is as follows:

Asp-Ala-Lys-His-His-Lys-Ala-Glu-Pro-GlyPro-Glu-Asp-Ser-Leu-His-Glu-Gln-Cys-SerPro-Trp-Arg-Lys-Asn-Ala-Cys-Cys-Ser-Val- ? Thr-Ser- ? -Glu-Ala- ? -Lys-Asp ? -Ser-Tyr-LeuTyr-. The seven first residues establish the overlap to the $\mathrm{N}$-terminal sequence.

$\mathrm{CNBr}-\mathrm{III}$ was shown to be 29 residues long 
based on amino acid analysis. Treatment with carboxypeptidase $Y$ released only isoleucine and, in smaller amounts, glycine, thus establishing this peptide as the C-terminal peptide of FBP. The sequence has been almost completed as follows:

Trp-Phe-Asp-Pro-Phe-Gin-Gly-Asn-ProAsn-Glu-Glu-Val-Ala-Arg-Phe-Tyr-Ala-GluAsn-Pro-Thr-Ser-Gly-Ser-Thr (Glx, Pro) GlyIle. $\mathrm{COOH}$.

We are now able to place the $\mathrm{CNBr}$-peptides in the correct order from the $\mathrm{N}$-terminus:

$\mathrm{CNBr}-\mathrm{IV} \rightarrow \mathrm{CNBr}-\mathrm{II} \rightarrow \mathrm{CNBr}-\mathrm{I} \rightarrow \mathrm{CNBr}-\mathrm{III}$

\subsection{Carbohydrate content}

Total carbohydrate content as determined by the phenol sulphuric acid method (4) varied depending on the particular preparation of folate binding protein used. Different preparations were found to contain varying amounts of carbohydrate $(7-10 \%)$. The preparation described in this article contained only $3 \%$. The only carbohydrate determined specifically was glucosamine. In all preparations investigated six moles of glucosamine were found per mole of FBP.

\subsection{Isoelectric focusing}

Isoelectric focusing of the protein gave rise to several peaks absorbing at $280 \mathrm{~nm}$. As seen in Figure 4 four major bands with pI's of $8.5,8.3$, 7.9 and 7.6 were observed together with two

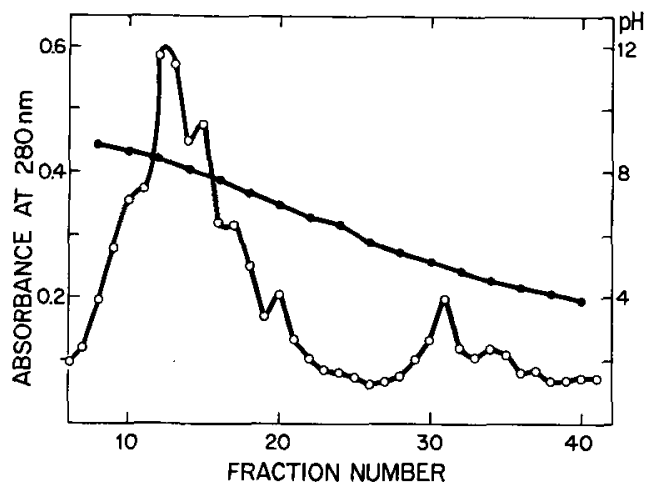

Figure 4. Isoelectric focusing of folate binding protein from cow's milk. - $-\mathrm{O}-$, Absorbance at $280 \mathrm{~nm}$. - . - , pH. Fractions of two $\mathrm{ml}$ collected. Experiment conducted at $4^{\circ} \mathrm{C}$ for 24 hours. minor bands with pI's of 7.0 and 5.0. Amino acid analysis of the individual major peaks gave identical results within the limits of experimental error. The reason for the multiple bands observed is not clear. It might be due to polymorphism although this assumption has not yet been proved, or it may be due to partial deamidation of asparagines or glutamines during isolation or pre-existing deamidation in the starting material. A similar observation has been made by RuBINOFF et al. (29), although the observed pl's were different for the goat protein.

\section{DISCUSSION}

Although several studies concerning the kinetics of folate binding to a protein in cow's milk have been published $(13,14,19)$, it has not hitherto been possible to obtain this protein in sufficient quantity to study its physico-chemical properties. With the method described in the present paper FBP has now been prepared in milligramme quantities enabling a thorough characterization.

The homogeneity of the preparation was substantiated by ultracentrifugation, SDS-gel electrophoresis and $\mathrm{N}$-terminal sequencing. In sedimentation velocity studies at $\mathrm{pH} 5.0$ the protein behaves as a single, symmetrical peak with a $\mathrm{s}_{20, \mathrm{w}}^{\circ}$ of $2.7 \mathrm{~S}$ indicating a globular monomer. Results from studies of the binding of folate to the protein at $\mathrm{pH} 7.4$ could only be explained if an aggregating system was assumed (14). This assumption has been verified by our studies in the analytical ultracentrifuge and the aggregation phenomenon is now under study using this technique.

Although the FBP appeared to be pure with respect to molecular size, SDS-gel electrophoresis showed that the main band always migrated faster than a contaminant present in varying amounts dependent on the batch tested. The batch used in the present studies had a very low content of contaminant (Figure 1D) but it has not yet been possible to produce a completely pure protein.

A very sensitive method to determine protein purity is to subject it to step-wise Edman degradation. As expected from the SDS-gel electrophoresis studies, more than one amino 
acid residue was identified per cycle. However, only two sequences were present and in a ratio of approx. 10:1, thus simplifying the identification of the two amino acids in each degradation cycle. As shown in 3.4.1. the minor component appears to have arisen from the major component by a limited proteolytic split between $\operatorname{Arg}_{8}$ and Alag. Milk is known to contain a proteolytic enzyme with trypsin-like activity (11). It is conceivable that this enzyme has acted upon the folate binding protein already before or during the purification procedure. This may explain why different batches contain different amounts of the minor component.

It is unclear why the $\mathrm{Arg}_{8}$-Ala 9 peptide bond should be more susceptible to hydrolysis than the $\mathrm{Arg}_{10}-\mathrm{Thr}_{11}$ bond. One explanation could be that the N-terminal segment may have sufficient freedom of movement to bring Arg $_{8}$-Ala 9 , but not $\operatorname{Arg}_{10}-\mathrm{Thr}_{11}$, in contact with the catalytic site of the protease.

Additional evidence for the suggestion that we are dealing with a homogeneous protein, but with a »ragged" $\mathrm{N}$-terminus, comes from characterization of the $\mathrm{CNBr}$ peptides. According to the amino acid composition only four $\mathrm{CNBr}$ peptides should exist. Three of these peptides could be isolated in the pure state by gel filtration on Bio-Gel P-30. If the minor component found by SDS-gel electrophoresis originated from a different peptide sequence we would expect to find more than four peptides after treatment with $\mathrm{CNBr}$ or to find impurities in the main peaks.

WAXMAN and collegues (29) also found an Ala as the N-terminal residue in FBP from goat's milk and they report a $\mathrm{Val}$ in position three. Only these two amino acids were reported and since FBP was suggested to be a polymorphous protein further delineation of the sequence was probably not attempted. Although we cannot exclude the possibility of polymorphism in FBP from cow's milk, we have sequenced about $50 \%$ of the molecule without observing any polymorphism.

The multiple isoelectric points found for FBP upon isoelectric focusing suggest that a varying content of amidated and free glutamic and/or aspartic acids is present. Also, variation in the carbohydrate content in different molecules may give rise to multiple isoelectric points.
Several reports concerning the molecular weight of FBP in milk from cow (30), goat (29) and man (32) have been published. All of these determinations are based on either gel filtration or SDS-gel electrophoresis. To our knowledge the present study is the first to make use of the more accurate analytical ultracentrifuge studies. The molecular weight, determined from sedimentation equilibrium studies at $\mathrm{pH} 5.0$ was found to be 29,800 . Two uncertainties in the calculation of the molecular weight must be taken into account: 1) The calculations are based on a carbohydrate content of $3.0 \%$, as determined by the phenol-sulphuric acid method (4). It has not yet been possible to make a rigorous determination of the individual carbohydrates involved. 2) An estimated value for the partial specific volume was used in the calculations. However, even with the errors inherent in the two entities it is estimated that the variation of the molecular weight will not be larger than \pm 2,000. Thus, the molecular weight of FBP from cow's milk determined by sedimentation equilibrium studies is considerably lower than the molecular weight of 35,000 determined from gel filtration $(14,30)$. In both of these investigations a $\mathrm{pH}$ above 7 was used. In light of our ultracentrifuge studies which indicate aggregation at $\mathrm{pH}$ 's above 6 it is quite conceivable that what has been observed as a symmetrical monomeric peak in gel filtration was in fact a mixture of monomer and dimer in rapid equilibrium. If the latter suggestion is correct, a molecular weight between that of the monomer and the dimer will be observed, the actual value depending on the equilibrium constant. SALTER et al. (30) noted in their studies at $\mathrm{pH} 7.4$ a concentration dependent increase in molecular weight. At $\mathrm{pH} 5$ where our studies were conducted no such aggregation was observed as shown by the straight line in the plot of $\ln f$ versus $x^{2}$ (see Figure 2) and we believe therefore the molecular weight of $29,800 \pm 2,000$ to be correct.

The amino acid composition of FBP is calculated on the basis of a molecular weight of 29,000 and a carbohydrate content of $3.0 \%$. A comparison with the amino acid composition of FBP from goat milk shows close similarity to this protein apart from the discrepancies already noted (section 3.3). However, WAXMaN's group 
reports a molecular weight of 39,200 based on the amino acid composition and a carbohydrate content of 22 per cent. A recalculation of the molecular weight of goat FBP using the data of RUBiNOFF et al. (29) gave a molecular weight of 34,300 which is in reasonable agreement with our data considering the large difference in carbohydrate content 1 ).

The folate binding protein from cow's milk also appears to be a glycoprotein. Although the carbohydrate content varies from preparation to preparation, it has always been considerably lower than what is found in FBP from goat (29) $-22 \%$. The preparation described in this article had the lowest carbohydrate content yet found. It should be noted that the six glucosamine residues found per mole of FBP account for the 3\% total carbohydrate determined by the phenol-sulphuric acid method. Carbohydrate hydrolyzing enzymes are known to exist in milk (11) and it is therefore tempting to suggest that the variable content of carbohydrate in purified folate binding protein is due to different degree of hydrolysis.

No attempt has as yet been made to determine the disulfide bridges in FBP, but as already mentioned above, half the sequence of FBP has been delineated from work with the cyanogen bromide fragments and the partial sequence can be represented as follows:

\section{$\mathrm{NH}_{2}$-ALA-GLN-ALA-PRO-ARG-THR-PRO-ARG-ALA-ÄRG-} 20

THR-ASP-LEU-LEU-ASN-VAL-CYS-MET-ASP-ALALYS-HIS-HIS-LYS-ALA-GLU-PRO-GLY-PRO-GLULYS-HIS-HIS-LYS-ALA-GLU-PRO-GLY-PRO-GLUASP-SER-LEU-HIS-GLU-GLN-CYS-SER-PRO-TRPARG-LYS-ASN-ALA-CYS-CYS-SER-VAL- $\quad$-THR60

SER- - GLY-ALA- -LYS-ASP- -SER-TYRLEU-TYR- $\longleftarrow 26$ RESIDUES $\longrightarrow$ MET-GLU-PRO-ALA-CYS-LYS-ARG-HIS-PHE-ILE-
GLN-ASP-THR-CYS-LEU-TYR-GLU-CYS-SER-PROASN-LEU-GLY-PRO- - - ARG-GLU-VAL-ASNGLN- 100 RESIDUES $\longrightarrow-$ MET-TRP-PHE-ASP-PRO-PHE-GLN-GLY-ASN-PROASN-GLU-GLU-VAL-ALA-ARG-PHE-TYR-ALA-GLUASN-PRO-THR-SER-GLY-SER-THR(GLU,PRO)GLYILE-COOH

\section{ACKNOWLEDGEMENTS}

We wish to thank professor MARTIN OTTESEN for many helpful discussions. The skilled technical assistance of Bodil Corneluussen, Solveig Nordlunde, Jytte Rasmussen and LoNe SøRenSEN is gratefully acknowledged.

\section{REFERENCES}

1. BeGG,G. S. \& F. J. Morgan: A non-volatile buffer with improved performance in automated protein sequencing. FEBS Lett. 66, 243-245 (1976)

2. Chervenko, C. H.: Long column meniscus depletion sedimentation equilibrium technique for the analytical ultracentrifuge. Anal. Biochem. 34, 24-29 (1970)

3. Cohn,E. J. \& J. T. Edsall: Proteins, amino acids and peptides, Reinhold, New York (1943)

4. Dubois, M., K. A. Gilles, J. E. Hamilton, P. A. Rebers \& F. SMith: Colorimetric method for determination of sugars and related substances. Anal. Chem. 28, 350-356 (1956)

5. Edman, P. \& A. Henschen: In: Protein sequence determination 2nd ed., S. B. Needleman ed., Springer-Verlag, Berlin, pp. 262 (1975)

6. Ellman, G. L.: Tissue sulfhydryl groups. Arch. Biochem. Biophys. 82, 70-77 (1959)

7. Fehrnström, H. \& U. MoberG: SDS and conventional polyacrylamide gel electrophoresis with LKB 2117 multiphor. LKB application note 306, 1-11 (1977)

\footnotetext{
1) It appears to us, that the WAXMAN group in their calculations by mistake may have used the molecular weights of the amino acid zwitter-ions instead of the amino acid residue (or carbohydrate residue).
} 
8. Friedman, M., L. H. Krull \& J. F. Cavins: The chromatographic determination of cystine and cystein residues in proteins as S- $\beta$-(4-pyridylethyl)cystein. J. Biol. Chem. 245, 3868-3871 (1970)

9. GibBons, R. A.: In: Glycoproteins. Their composition, structure and function. A. Gottschalk ed., Elsevier, Amsterdam, pp. 74-81 (1966)

10. Goodwin, T. W. \& R. A. Morton: The spectrophotometric determination of tyrosine and tryptophan in proteins. Biochem. J. 40, 628-632 (1946)

11. Groves, M. L.: In: Milk proteins, H. A. McKenzie ed., Academic Press pp. 385 (1971)

12. Hansen, S. I., J. Holm \& I. Lyngaye: Folate binding by human milk protein. Scand. J. Clin. Lab. Invest. 37, 363-367 (1977)

13. Hansen, S. I., J. Holm \& J. Lyngbye: Mechanism of folate binding in milk. Clinica Chim. Acta $75,321-324$ (1977)

14. Hansen, S. I., J. Holm \& J. LyngBye: Cooperative binding of folate to a protein isolated from cow's whey. Biochim. Biophys. Acta 535, 309318 (1978)

15. Hayashi, R., S. Moore \& W. H. Stein: Carboxypeptidase from yeast. J. Biol. Chem. 248, 2296-2302 (1973)

16. Henderson, G. B., E. M. Zevely \& F. M. HuenNEKENS: Purification and properties of a membrane-associated, folate-binding protein from Lactobacillus casei. J. Biol. Chem. 252, 37603765 (1977)

17. Hirs, C. H. W.: Performic acid oxidation. Methods Enzymol. 11, 197-199 (1967)

18. Holm, J., S. I. Hansen \& J. Lyngbye: Cooperative binding of $3 \mathrm{H}$-folate to a macromolecular high-affinity binder in sera from pregnant women. Abstract. XVII Congress of hematology, Paris 23-29 of July (1978)

19. Holm, J., S. I. HANSEN \& J. LyNGBye: Effect of methotrexate on folate binding to a folate binding protein in cow's milk. Acta pharmacol. et toxicol. $42,77-80$ (1978)

20. Huennekens, F. M., K. S. Vitols \& G. B. Henderson: Transport of folate compounds in bacterial and mammalian cells. Adv. Enzymol. 47, 313-346 (1978)

21. Kaufmann, B. T.: Methotrexate-agarose in the purification of dihydrofolatereductase. Methods Enzymol. 34, 272-281 (1974)
22. Klapper, D. G., C. E. Wilde III \& J. D. Capra: Automated amino acid sequence of small peptides utilizing polybrene. Anal. Biochem. 85, 126-131 (1978)

23. KulBe, K. D.: Rapid separation of phenyl hydantoin (PTH) amino acids by thin-layer chromatography on polyamide glass plates. Anal. Biochem. 44, 548-558 (1971)

24. Martin, B., I. Svendsen \& M. Ottesen: Use of carboxypeptidase $\mathrm{Y}$ for carboxy-terminal sequence determination in proteins. Carlsberg Res. Commun. 42, 99-102 (1977)

25. Mendez, E. \& C. Y. Lai: Regeneration of amino acids from thiazolinones formed in the Edman degradation. Anal. Biochem. 68, 47-53 (1975)

26. Penke,B., R. Ferenczi \& K. Kovács: A new acid hydrolysis method for determining tryptophan in peptides and proteins. Anal. Biochem. 60, 4550 (1974)

27. Petersen, C., V. Hasemann, B. Martin, J. T. Johansen, I. Suendsen \& M. Ottesen: The amino terminal sequence of superoxide dismutase from Saccharomyces cerevisiae. Carlsberg Res. Commun. 42, 391-395 (1977)

28. Petersen, C.: Isolering og karakterisering af superoxid dismutase fra gær. Dissertation, University of Copenhagen (1978)

29. Rubinoff, M., C. Schreiber \& S. Waxman: The isolation and characterization of the folate binding protein from goat milk. FEBS lett. 75 , 244-248 (1977)

30. Salter, D. N., J. E. Ford, K. J. Scott \& P. ANDREWS: Isolation of the folate-binding protein from cow's milk by the use of affinity chromatography. FEBS Lett. 20, 302-306 (1972).

31. Selhub, J. \& N. Grossowicz: Chemical fixation of folate binding protein to activated sepharose. FEBS Lett. 35, 76-78 (1973)

32. Waxman, S. \& C. Schreiber: The purification and characterization of the low molecular weight human folate binding protein using affinity chromatography. Biochemistry 14, 5422-5428 (1975)

33. Waxman, S.: The role of folate binding protein in folate metabolism. In: Chemistry and biology of pteridines. W. Pfleiderer ed., Walter de Gruyter, Berlin (1975)

34. Zimmerman, C. L., E. Apella \& J. J. Pisano: Rapid analysis of amino acid phenylhydantoins by high-performance liquid chromatography. Anal. Biochem. 77, 569-573 (1977) 